\title{
The Effect of Financial Condition on Firm Value: A Comparative Study
}

\author{
Dwiyanjana Santyo Nugroho*
}

AFFILIATION:

1,2,3 Faculty of Economics and Business, Universitas Indonesia, Indonesia

\section{*CORRESPONDENCE:}

santyonug@gmail.com

THIS ARTICLE IS AVAILABLE IN:

https://ojs.unud.ac.id/index.php/jiab

DOI:

10.24843/JIAB.2021.v16.i02.p02

CITATION:

Nugroho, D. S. (2021). The Effect of Financial Condition on Firm Value: A Comparative Study. Jurnal IImiah Akuntansi dan Bisnis, 16 (2), 199217.

\section{ARTICLE HISTORY}

\section{Received:}

11 November 2020

Revised:

10 March 2021

Accepted:

19 April 2021

\begin{abstract}
This study analyzes a company's financial condition on firm value. We also evaluated the difference in firm value between corporate sectors affected and unaffected by the COVID-19 pandemic. The regression analysis model used is the random effect model as well as the difference-in-difference technique. The study uses data from the company's interim financial reports for the first and second quarters of 2018, 2019, and 2020. We found that firm size and leverage influence firm values. This applies to companies in the affected sectors, such as hotel, restaurant, and tourism sub-sectors, and unaffected sectors, such as health, pharmacy, and telecommunication sub-sectors. We also found that firm values in affected and unaffected sectors, before and during COVID-19, do not significantly differ.
\end{abstract}

Keywords: COVID-19, financial condition, firm value

\section{Introduction}

Regarding the recent outbreak of the COVID-19 pandemic, different government's responses in a country bring different effects on the economy. Hubei province in China and the Lombardy region in Italy, which implemented a lockdown to break the chain of the novel coronavirus' spread, found that the public health crisis had substantially impacted firm value (Ding et al., 2020). Instead of a lockdown, Indonesia decided to opt for the implementation of the Large-Scale Social Restrictions (PSBB) as stipulated under the Government Regulation Number 21 of 2020. The enactment of the PSBB hit hard on several industrial sectors whose movements were limited due to social distancing. On the other hand, some other industrial sectors have benefited from this pandemic. During the pandemic, companies engaged in the pharmaceutical and health sectors will have a much busier operating flow compared to that of other sectors due to the increase in demands. On top of that, the pandemic and PSBB had obliged in-person activities to be adapted into online activities, which consequently increased the need for long-distance communication facilitated by telecommunications companies. The uncertain situation due to this outbreak positively affects the capital market (lyke, 2020; Phan \& Narayan, 2020). It is believed that the pandemic's impact on Indonesia's financial markets could likely be much more significant than the 2018 shocks (Indrawati et al., 2020). 


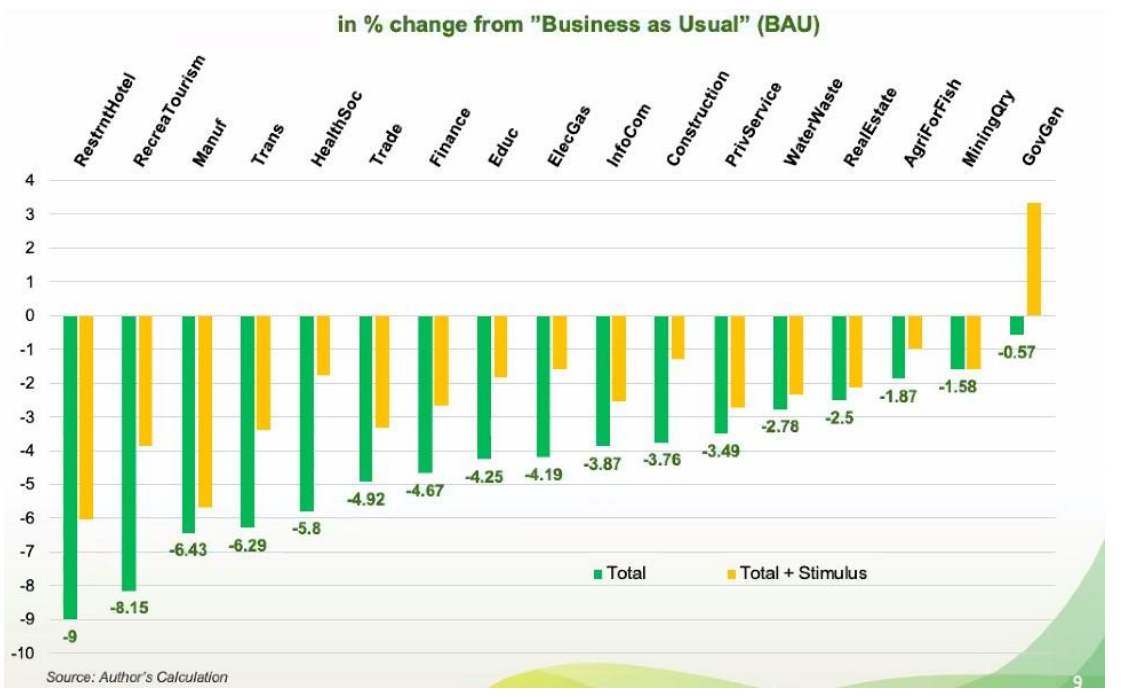

Figure 1. Percentage change from $\mathrm{BAU}$ in each industrial sector Source: LPEM FEB UI (2020)

A research conducted by the Institute for Economic and Community Research, Faculty of Economics and Business, Universitas Indonesia (Halimatussadiah et al., 2020), as illustrated in Figure 1, revealed that the sectors most affected by COVID-19 are the restaurant and hotel, as well as recreation and tourism with their percentage change rate for "Business as Usual" (BAU), to be used later, e.g., Fig.1, of only $-9 \%$ and $-8.15 \%$, respectively. This finding is supported by Hadiwardoyo (2020), who states that the business sectors that are considerably hit are those that rely on crowds (such as tourism, events, or shows) and supporting businesses, such as restaurants and hotels. In their analysis, Revindo \& Alta (2020) also evaluated various scenarios that clearly illustrate that tourism is one of the sectors that crashed due to social restrictions.

Nevertheless, not all industrial sectors experienced the same losses. As explained above, specific sectors benefited from the COVID-19 outbreak and promulgation of PSBB policy. In this study, it is termed as industries that are unaffected by COVID-19. As stated by Hadiwardoyo (2020), business sectors with the potential to benefit from social restrictions are mobile operators, Internet providers, health sector, providers of sanitizers, soap, and their derivative products that fall within the scope of the pharmaceutical sector.

The available literature and empirical evidence regarding the firm's value lack conceptual clarification of its determinants (Gharaibeh \& Qader, 2017). Many scholars have linked the impacts of the pandemic crisis to the 2008 economic crisis, but not many have assessed as to how the industries in the capital market react to COVID-19. Ding et al. (2020) examined the correlation between the presence of COVID-19 as well as firm exposure and firm value. Quite in the same vein, Shen et al. (2020) also investigated the impacts of COVID-19 on company performance. Both of these studies yielded similar results, showing that the virus's emergence has a negative influence on company performance. There are three types of elements representing a company's value, namely technical, external, and internal. Technical factors are more specialized and psychological, such as the stock trading volume, value of stock trading transactions, and the tendency for the stock prices' ups and downs. The fundamental factors are external 
and internal because they relate to the investors' decision-making process in the capital market. According to Sujoko \& Soebiantoro (2009), internal factors are a set of variables that a company can control, whereas external factors are those beyond their control, including interest rates and capital market conditions. In contrast, the most important internal factor is the company's own financial condition, which according to Ding et al. (2020), is reflected in firm size, leverage, cash, and profitability. Ding et al. (2020) claimed that they are the first to investigate this issue. Their findings explicitly showed that companies with more substantial financial conditions before COVID-19 experience better share price reactions than companies with a lot of debt, less corporate cash, and lower profits. By examining the companies' characteristics altogether, we can identify the relationship between individual company's characteristics and the reaction of the capital market to the pandemic better. Regarding stock prices, Ding et al.(2020) and Nugroho \& Pertiwi (2020) both found the evidence showing that stock prices had seen a significant downward trend compared to before the outbreak. However, there is no similar research linking the company's financial condition to the firm value during the pandemic. Ergo, this gap will be explained in this investigation.

Investigating how COVID-19 impacts a country's economy has the utmost urgency, for it enables researchers to find advanced solutions or inputs in tackling this pandemic. Even though the recent outbreak has posed multifarious challenges, it provides scholars with a rare opportunity to investigate these questions (Ding et al., 2020). The current study is conducted to serve as a literature on firm value, especially at the event of an economic crisis caused by external factors, and the latest literature on economic conditions during the COVID-19 pandemic. Similar to the study conducted by Ding et al. (2020), our research relates to the literature on the effects of outbreaks or health crises (e.g. Foster, 1995; Nunn \& Qian, 2010; Weil, 2007; Zhang et al., 2003).

Our research uses the Difference-in-Difference (DiD) technique, as also employed by Shen et al. (2020). It compares the quarter before the pandemic to when the pandemic hit between the two positively-affected sectors: hotel, restaurant, and tourism. The other industries that are negatively affected are health, pharmacy, and telecommunication. The current study will fill the literature gap regarding the industrial economy's condition during the crisis. This way, we hope to assist the government in formulating and issuing regulations to bolster the slumping economy's competitiveness. Additionally, this study can assist the investors in preparing their own analyses and reading of a company's current condition, in relation to whether or not it is still prospective, considering that our research implicitly reflects the development of conditions in several industrial sectors. Company managers cannot maintain the company's value if they do not recognize the factors that influence it and its size and direction.

A number of past studies have elucidated the correlation between capital markets and firm value, and some theories can explain this phenomenon well. The firm's value is a particular condition that a company has achieved as a picture of public confidence after operational activity for several years (Maksum, \& Sirojuzilam, 2018). The firm value in the capital market is market value, reflected in the stock price. Stock prices indicate how efficient a company's management level is. Profits and losses are the results of changes in stock prices (Putra et al., 2019). Markets with low information asymmetry can be seen from their sensitivity to company value changes that are easy for investors to see through their stock prices rather than investors calculating to find its 
intrinsic value. The higher the stock price translates to the increase of the shareholder's prosperity. The market price also shows the value of the company. The stock price is calculated from the present value of the dividend to be received, so the higher is also the company's value related to the purpose of the company itself that is maximizing shareholder wealth (Maksum \& Sirojuzilam, 2018).

The leading theory used as the basis is the theory that Spence first introduced in 1973 , which states that signaling theory is a theory related to reducing information asymmetry between two parties (Spence, 2002) and explaining the relationship between accounting information and firm's market value. In their review, Connelly et al., (2011) state that managers intensively send positive signals to investors as a tool to show that the company has a better performance than other companies. Through this theory, a firm value can be improved by overcoming asymmetric information, that is by providing signals to other investors in the form of reliable financial information to develop confidence in future growth prospects (Adiputra \& Hermawan, 2020). As explained above, firm value is a concern of investors, which can be influenced by the company's financial statements.

An accurate financial information of a company is of paramount importance for the investors. It gives them a comprehensive and holistic description on how the company performs. In order to determine the company's value, investors use financial ratios, one of which is Tobin's $Q$. Tobin's $Q$ is considered to provide the best information on the fundamental aspects and the extent to which the outsiders assesses the company from various aspects, including from the investors (Maksum \& Sirojuzilam, 2018). Therefore, companies are always required to improve their performance, that is to increase the company value (Suartawan \& Yasa, 2016). Ding et al., (2020) formulated four necessary measurements that reflect a company's financial condition to calculate and predict the current and future value. When the pandemic crisis depresses company sales, it seeks liquidity to cover costs. Then, the capital market considers cash reserves, leverage, and company profitability when re-evaluating the company value (Nugroho \& Pertiwi, 2020).

The capital market appreciates the value of the company through stock prices to provide confidence to investors. Investors tend to trust companies with large asset capitalization, which shows the company's ability to manage its assets optimally. Investors also consider companies that have considerable assets to adapt to the pandemic to maintain the stability of company value in the capital market. Several previous studies conclude that the size of a company positively affects the firm value with several considerations, such as diversification, product and service portfolios, guarantees, business cycle, company age, company image, and capital structure (Aggarwal \& Padhan, 2017; Gill \& Obradovich, 2012; Prieto \& Lee, 2019). However, company size can also negatively affect its value, as found by Adiputra \& Hermawan (2020). Either in an industrial condition affected by COVID-19 or not, we predict that its value will increase in accordance with the company size.

$\mathrm{H}_{1 \mathrm{a}}$ : Firm size has a positive effect on the firm value of the industrial sectors that are affected by COVID-19.

$\mathrm{H}_{1 \mathrm{~b}}$ : Firm size has a positive effect on the firm value of the industrial sectors that are unaffected by COVID-19.

Leverage is a large or small picture of a company's debt that is utilized to finance its business activities. During the economic recession due to the COVID-19 pandemic, 


\section{Nugroho \\ The Effect of Financial Condition on Firm Value: A Comparative Study}

Ramelli \& Wagner (2020) revealed in their research that high leverage exacerbates the company's value due to a shift in stock prices in the capital market. Leverage becomes influential if the company experiences a profoundly substantial decline in value due to the pandemic. As explained by the trade-off theory, when the capital structure's position is optimal, each of the company's debt increases firm value and vice versa (Wahyuni, 2018).

High leverage can incline firm value due to tax protection (Endri \& Fathony, 2020). Management can use leverage in providing signals to stakeholders so that its use needs to be considered. Leverage is closely related to company risk. In other words, if the company's risk is high enough, investors will stay away from the company and cause the stock price to decline. Moreover, it also relates to how a company manages its funding sources. A company with sufficient resources will maximize funding from within (stock) rather than by borrowing from creditors to reflect good company value, which can strengthen the stock prices. For industrial sector firms affected by COVID-19, the high leverage will decline their value, since it is considered to have a high risk of default, especially with the condition of the industry being damaged, causing the investors to avoid risks. This is because too much credit will eventually cause the company to fail to pay for the debts. Meanwhile, for companies that are unaffected by COVID-19, high leverage can reflect a signal that they are in a high competition state to be a positive one.

$\mathrm{H}_{2 \mathrm{a}}$. Leverage has a negative effect on the firm value of the industrial sectors that are affected by COVID-19.

$\mathrm{H}_{2 b}$. Leverage has a positive effect on firm value in the industrial sectors that are unaffected by COVID-19.

Ginglinger \& Saddour (2012) state that cash holding is the amount of cash that is held by a company to carry out their activities. Cash becomes very essential when companies experience a profoundly-severe price decline due to pandemics. De Vito \& Gómez, (2020) postulate that the high cash owned by the company makes it more possible for the company to survive the pandemic and to survive in an excellent position to invest in a recovery period. In their research, Ramelli \& Wagner (2020) revealed that low cash worsens firm value by shifting stock prices in the capital market. The smaller the cash holdings that are adjusted to the company's conditions, the more the impact on the increase of company value.

Company cash brings benefits and costs. Jensen (1986) argues that too much free cash flow leads to internal insufficiency and wastes the company resources, further resulting in agency costs as a burden on shareholders. As a result, an optimal cash level may exist where company value is maximized (Martínez-Sola et al., 2013). Circulating cash can signal the company to stakeholders, which shows how management is implementing its financial strategy. The company always strives to maintain the stability of cash flow solely to maintain the investors' confidence, as reflected in the capital market's firm value. Cash managed by the company is also based on the company's competitive environment in the industry. Companies in sectors affected by COVID-19 will seek to boost company output, whereas the companies in sectors that are not affected by COVID-19 will strive to maintain cash stability to maintain company value in the capital market.

$\mathrm{H}_{3 \mathrm{a}}$ : Cash has a negative effect on the firm value of the industrial sectors that are affected by COVID-19. 


\section{Nugroho \\ The Effect of Financial Condition on Firm Value: A Comparative Study}

$\mathrm{H}_{3 \mathrm{~b}}$ : Cash has a positive effect on the firm value of the industrial sectors that are not affected by COVID-19.

Profitability ratios are useful in measuring the company's success, and they serve as indicators to evaluate its manager's performance. High profitability demonstrates good company prospects. Therefore, investors give positive responses to these signals, for it is expected to improve the firm value. In contrast, low profitability shows that a company is not in a good condition, resulting in a negative response on the shares from the investors (Endri \& Fathony, 2020). As more profitability leads to higher retained earnings, companies prioritize the utilization of internal funds, and issue debt and equity as their last resort. Consequently, the firm value will increase as the profitability becomes higher (Aggarwal \& Padhan, 2017; Shah \& Kausar, 2012). The higher the ability to earn profits, the greater the return the investors expect. This creates a better firm value (Brigham \& Houston, 2014). For both industrial sectors that are affected and unaffected by COVID-19, we predict that the greater the company's profitability, the higher company's value.

$\mathrm{H}_{4 a}$ : Profitability has a positive effect on the firm value of the industrial sectors that are affected by COVID-19.

$\mathrm{H}_{4 b}$ : Profitability has a positive effect on firm value of the industrial sectors that are unaffected by COVID-19.

Ramelli \& Wagner (2020) revealed that the capital market experienced a reaction as a result of the COVID-19 outbreak. This is indicated by the existence of economic instability in the future. This pandemic has disrupted global markets, meaning that stock prices worldwide will see significant changes afterwards, especially for the industrial sectors whose activities are limited due to policies issued by the government to prevent the spread of the widespread outbreak. Shen et al. (2020) proved that COVID-19 poses negative impacts on company's performance. Such impacts will appear when the scale of the company's investment or the company's sales turnover is smaller. The adverse impacts of COVID-19 on company's performance will be more significant in industrial areas that are seriously affected.

Ding et al. (2020) found that companies operating at the disease's epicenter were most severely-affected by the COVID-19 outbreak. This indicates that there is a level of damage due to the pandemic. Companies whose operational activities have been disrupted due to the outbreak have benefited from this pandemic. We predict a noteworthy difference in firm values between companies that are negatively affected and those that are unaffected by COVID-19.

$\mathrm{H}_{5}$ : The firm value of the industrial sectors affected by COVID-19 has a significant difference compared to the firm value of the industrial sectors that are unaffected by it.

\section{Research Method}

This study examines companies in the sub-sector of hotels, tourism, and restaurants categorized as affected sectors, whereas the unaffected industries are the sub-sector of health, pharmacy, and telecommunication listed on the Indonesia Stock Exchange (IDX). The data collected are financial reports and interim financial reports for the first and second quarters of 2018, 2019, and 2020. Financial report data were obtained through the IDX website (www.idx.co.id) and its website, in case the financial statements are not available on the IDX portal. The purpose of using interim reports of the first and second 
quarter is to compare quarterly financial statements and avoid financial reporting bias that can be cyclical when trying to compare optimally. The research sample was chosen using the purposive sampling method. Sample selection was determined based on criteria tailored to the objectives of the study.

The most recent data were taken in October 2020. However, six companies had not published interim reports for the second quarter of 2020, so they were eliminated from the research sample. Companies that had just started IPOs from 2018 - 2020 were also removed because the research observation period started in 2018, meaning that those companies did not have the complete data needed. Hence, the sample consists of 18 companies in the hotel, tourism, restaurant sub-sectors, and 18 companies from the pharmaceutical, health, and telecommunications sub-sectors.

As also used in previous studies, Tobin's $Q$ was utilized in this study to measure the firm value. Investors use the financial ratios to learn about a company's market value. These ratios can indicate management regarding investor appraisal of the company's performance in the past and its prospects in the future (Maksum \& Sirojuzilam, 2018). This indicator is calculated by dividing the market value of assets by the book value of assets, where it is defined as the market value of equity (market capitalization) plus book value of assets minus book value of equity (Adams \& Ferreira, 2009; Batten \& Vo, 2019; Rjiba et al., 2020). Before the outbreak, the financial condition of a company could shape a response to any developments in COVID-19 cases and their impacts on its operations. In evaluating this financial condition, following the measurements from Ding et al. (2020) there are four essential financial characteristics, namely company size, leverage, cash, and ROA. Firm size is measured using the natural logarithm of total assets. Leverage is measured using the ratio of total liabilities divided by total assets. Cash is measured using total cash and cash equivalents plus short-term investment divided by total assets. ROA is measured as the ratio of net income to total assets.

Table 1. Sample Selection Criteria

\begin{tabular}{|c|c|c|}
\hline Criteria & $\begin{array}{l}\text { Hotel, Restaurant, } \\
\text { Tourism Sub-Sector }\end{array}$ & $\begin{array}{r}\text { Health, Pharmacy, } \\
\text { Telecommunication } \\
\text { Sub-Sector }\end{array}$ \\
\hline $\begin{array}{l}\text { The industrial sub-sector population } \\
\text { was affected and unaffected by } \\
\text { COVID-19 }\end{array}$ & 35 & 22 \\
\hline $\begin{array}{l}\text { Companies that did not publish } \\
\text { interim financial reports between } \\
\text { the first quarter of } 2018 \text { and the } \\
\text { second quarter of } 2020\end{array}$ & (6) & (0) \\
\hline $\begin{array}{l}\text { Companies that went public in } 2018 \text { - } \\
2020\end{array}$ & (11) & (4) \\
\hline Total Sample Companies & 18 & 18 \\
\hline
\end{tabular}

Source: Processed Data, 2020 


\section{Nugroho}

The Effect of Financial Condition on Firm Value: A Comparative Study

The test in this investigation uses a random effect model regression analysis. The choice of analysis method was confirmed after conducting the Hausman Test and Breush and Pagan Lagrangian testing, the discussion of which is presented in the next section. The statistical analysis tool used was STATA 15. The classic assumption test that was tested was a multicollinearity problem. In contrast, the heteroscedasticity test was not performed because the regression analysis model used a random effect model, which already used GLS regression to be free from heteroscedasticity problems. This study also controls the research bias by tying up differences between years of study and firms. The problem of multicollinearity in this study's data was corrected using the generalized method of moments (GMM) analysis method.

To test the hypothesis, this study follows the first regression model using multiple linear regression as shown in Eq.1 and Eq.2, and the second regression model using the Difference in Difference (DiD) approach shown in Eq. 3. Thus, we estimated the research model as follows:

$$
\begin{aligned}
& \text { VALUE_Impacted }_{(i, t)}=\alpha+\beta_{1} \operatorname{SIZE}_{(i, t)}+\beta_{2} \operatorname{LEV}_{(i, t)}+\beta_{3} \mathrm{CASH}_{(i, t)}+\beta_{4} \operatorname{ROA}_{(i, t)}+ \\
& \beta_{5} \mathrm{OCF}_{(i, t)}+\beta_{6} \mathrm{SALES}_{(i, t)}+\beta_{7} \mathrm{CAPE}_{(i, t)}+\beta_{8} \mathrm{ACC}_{(i, \mathrm{t})}+\varepsilon_{(i, t)} \text {. } \\
& \text { VALUE_NonImpacted }_{(i, t)}=\alpha+\beta_{1} \operatorname{SIZE}_{(i, t)}+\beta_{2} \operatorname{LEV}_{(i, t)}+\beta_{3} \operatorname{CASH}_{(i, t)}+\beta_{4} \operatorname{ROA}_{(i, t)}+ \\
& \beta_{5} \mathrm{OCF}_{(i, t)}+\beta_{6} \operatorname{SALES}_{(i, t)}+\beta_{7} \operatorname{CAPE}_{(i, t)}+\beta_{8} \operatorname{ACC}_{(i, t)}+\varepsilon_{(i, t)} . \\
& \operatorname{VALUE}_{(i, t)} \quad=\alpha+\gamma_{1} \text { time }(i, t)+\gamma_{2} \operatorname{affected}_{(i, t)}+\gamma_{3} \text { time*affected } d_{(i, t)} \ldots \ldots
\end{aligned}
$$

Notes:

VALUE_Impacted : firm value for impacted sectors

VALUE_Nonlmpacted : firm value for not impacted sectors

VALUE : firm value for all sectors

SIZE $\quad$ : firm size

LEV : leverage

CASH : cash

ROA $\quad$ : return on asset

SALES : sales growth

OCF : operating cash flow

CAPE : capital expenditure

ACC : total accrual

e : error

Time $\quad:$ the difference in the point in time of the observation year

Affected : dummy industrial sector affected by COVID-19

In the first regression equation, the primary independent variable is the firm's financial condition, which consists of four variables, consisting of firm size, leverage, cash, and ROA. This is in line with the study conducted by Ding et al. (2020) that evaluates how the company's financial condition before 2020 shaped its share price during the pandemic. To minimize bias as a result of the lack of scope that affects the dependent variable, this study also uses controlled variables, such as sales growth, capital expenditure, total accruals, and operating cash flow.

The second regression equation uses the difference in difference (DiD) approach, which assesses whether the COVID-19 outbreak causes a substantial 
difference in the comparison of firm value between industrial sectors affected and unaffected by COVID-19. The period used for treatment is quarter I-II of 2020 compared to quarter I-II of 2019 and quarter I-II 2018. The measure of whether the pandemic has any effect is measured by dividing the two sectors, where it is measured using dummy variables. The hospitality, tourism, and restaurant sub-sector industry is 1 , whereas the health, pharmaceutical, and telecommunication sub-sector industry is 0 . Then, the two industries' divisions are treated and interacted between the first and second quarter of 2020 compared to the first quarter of 2019 and 2018.

\section{Result and Discussion}

In determining which regression analysis model to use, there are two stages of testing conducted in this study. The comparisons in The Hausman Test and the Breush Pagan Lagrangian becomes the basis for the selection of the most appropriate model (Widarjono, 2018). Table 2. and Table 3. show that the random effect model is a regression analysis model that is more appropriate to use in analyzing testing, especially compared to the fixed effect or standard model. To assess the affected and unaffected industrial sectors, we both used the Random Effect Model.

The use of the random effect analysis model made this study only test the classic assumptions for multicollinearity. The heteroscedasticity test was not administered since in the random effect model analysis, the regression used was the GLS Regression which had answered or eliminated the problem of heteroscedasticity. Nonetheless, in the observational data of this study, there are multicollinearity problems. This is indicated by a VIF value of more than 10 . This indicates a strong correlation between variables. The multicollinearity problem is corrected by using the GMM estimator regression so that the test results used are the regression results that have been tightened using the estimator. The sectors unaffected by COVID-19 consist of the health, pharmaceutical, and telecommunications sub-sectors.

Table 4. illustrates the statistical descriptions of the variables used in the empirical models. The data are comprised of 36 companies which consist of 216 observation samples starting from the first quarter of 2018 to the second quarter of 2020. The average company value for the industrial sector affected by COVID-19 was $104,557.9$, whereas for the industrial sector not affected was 3,536,807. This indicates that there is a considerable difference in the value that companies have between the two sectors.

The companies' size in the affected sector has an average of 26 , whereas the unaffected sector has an average of 22. It means that firm size in the affected sectors and unaffected sectors are similar, so companies' assets are relatively comparable. The average values of leverage or debt ratio owned by companies in sectors affected and unaffected by COVID-19 were $37 \%$ and $44 \%$ respectively. This means, with a comparable company size, the leverage ratio owned by the companies unaffected by the outbreak is

Table 2. Selection Test of the Regression Analysis Model for the Covid-19 Affected Sector

\begin{tabular}{lll}
\hline Model Test & Significance & Result \\
\hline Hausman Test & 0.8793 & Random effect \\
Breush and Pagan Lagrangian & 0.0000 & Random effect \\
\hline
\end{tabular}

Source: Processed Data, 2020 
Nugroho

The Effect of Financial Condition on Firm Value: A Comparative Study

Table 3. Selection Test of the Regression Analysis Model for the Covid-19 Unaffected Sector

\begin{tabular}{lll}
\hline Model Test & Significance & Result \\
\hline Hausman Test & 0.9999 & Random effect \\
Breush and Pagan Lagrangian & 0.0000 & Random effect
\end{tabular}

Source: Processed Data, 2020

greater than the leverage ratio owned by the companies in the affected sector.

The average cash reserve ratio for the industrial sector that was affected was $42 \%$, while for the industrial sector that was not affected was $19 \%$. This indicates that the companies in the affected sectors have more cash reserves than the non-impacted industrial sectors. The profitability of companies in the sectors affected by pandemic was $-3 \%$, whereas those not affected had a profitability ratio of $-22 \%$. In general, the two sectors were unable to generate profits, which is shown by the negative profitability, which might be due to the pandemic.

The pre-pandemic financial conditions have shaped the reaction of the capital market during the outbreak. The impacts on companies' operationalization are very pronounced, particularly for companies whose activities conflict with the implementation of social restrictions. Conversely, companies that benefit due to

Table 4. Descriptive Statistics

\begin{tabular}{lrrrr}
\hline Variable & Mean & \multicolumn{2}{l}{ Std Dev } & Min \\
\hline Panel A: The COVID-19's Affected Sector & & & \\
\hline Value_Impacted & $104,557.900$ & $448,360.700$ & 0.505 & $2,560,865.000$ \\
SIZE & 26.001 & 3.720 & 14.238 & 30.994 \\
LEV & 0.374 & 0.255 & 0.014 & 0.873 \\
CASH & 0.421 & 0.213 & 0.050 & 0.991 \\
ROA & -0.003 & 0.069 & -0.378 & 0.297 \\
OCF & 0.005 & 0.032 & -0.057 & 0.168 \\
SALES & -0.327 & 0.929 & -5.342 & 0.494 \\
CAPE & -0.013 & 0.040 & -0.269 & 0.074 \\
ACC & $2.50 E+09$ & $2.41 \mathrm{E}+10$ & $-1.12 \mathrm{E}+10$ & $2.42 \mathrm{E}+11$ \\
\hline Panel B: The COVID-19's Unaffected Sector & & & \\
\hline Value_NonImpacted & $3,536,807.000$ & $11,400,000.000$ & 0.502 & $571,000,00.000$ \\
SIZE & 22.182 & 6.578 & 9.684 & 31.180 \\
LEV & 0.441 & 0.232 & 0.000 & 0.936 \\
CASH & 19.009 & 129.434 & 0.208 & 965.675 \\
ROA & -0.224 & 1.785 & -15.252 & 0.313 \\
OCF & 0.030 & 0.069 & -0.354 & 0.283 \\
SALES & 0.029 & 0.269 & -1.422 & 0.480 \\
CAPE & -0.032 & 0.030 & -0.168 & 0.007 \\
ACC & $-1.29 \mathrm{e}+09$ & $1.36 \mathrm{e}+10$ & $-7.90 \mathrm{e}+10$ & $5.37 \mathrm{e}+10$ \\
\hline The & & &
\end{tabular}

The sample consists of 216 firm-year observations for the period from quarter I 2018 to quarter II 2020. Panel A consists of companies in the sub-sectors of hotels, tourism, and restaurants. Panel $B$ consists of companies in the health, pharmaceutical, and telecommunications subsectors.

Source: Processed Data, 2020 
growing demand for new needs emerge after the pandemic. Hypothesis testing takes into account the differences in the company and the years of observation. These two factors are controlled so as to not produce biased output. We found that, among the four primary financial conditions of a company, firm size and leverage significantly affect the firm value both for companies operating in sectors affected or not affected by COVID-19.

From Table 5., the significance of the company size for the unaffected and the affected sector is 0.000 , which indicates that the results are influential. However, the direction of the two sectors' coefficients is similar, so that it is not following initial expectations. We predicted that the relationship between firm size and firm value would be positive, but the statistical results showed a negative direction. This can be interpreted that investors indeed pay attention to company size in determining company value. However, the greater the size of the company, the lower the firm's value.

The growth in total assets owned by the company is not necessarily able to increase the firm's value in investors' views. Large-scale companies are not always able to optimize their productivity. Hence, company profitability is low. This can also be caused by the management of assets that is not optimal in the company. Larger companies do not guarantee greater profits compared to the companies with smaller assets (Endri \& Fathony, 2020). Similarly, Setiadharma \& Machali (2017) view that firm size negatively affects firm value even though it is not substantial. They argue investors in Indonesia neither take accounting information into account nor think about capital structure and company size as the basis for investment decisions. Adiputra \& Hermawan (2020) added that Indonesia's irrational investors could not process and interpret information correctly.

Table 5. Multiple Linear Regression Test Results

\begin{tabular}{|c|c|c|c|c|}
\hline \multirow[b]{2}{*}{ Variables } & \multicolumn{2}{|c|}{ COVID-19 Affected Sectors } & \multicolumn{2}{|c|}{ COVID-19 Unaffected Sectors } \\
\hline & Coefficient & Significance & Coefficient & Significance \\
\hline SIZE & $-72,602.800$ & $0.000 * * *$ & $-809,495.300$ & $0.000 * * *$ \\
\hline LEV & $141,450.800$ & $0.037 * *$ & 1.256 & $0.010 * * *$ \\
\hline CASH & $-54,381.190$ & 0.614 & $17,595.490$ & 0.117 \\
\hline ROA & $200,110.500$ & 0.593 & $1,029,180.000$ & 0.218 \\
\hline OCF & $2,853,355.000$ & $0.017 * *$ & 1.511 & $0.085^{*}$ \\
\hline SALES & $-9,859.210$ & 0.575 & $154,726.400$ & 0.927 \\
\hline CAPE & $-4,210,962.000$ & $0.045^{* *}$ & -4.500 & 0.117 \\
\hline ACC & 1.556 & $0.035^{* *}$ & 0.000 & 0.221 \\
\hline Firm random effect & Yes & & Yes & \\
\hline Year random effect & Yes & & Yes & \\
\hline $\mathrm{N}$ & 108 & & 108 & \\
\hline R2 & $62.29 \%$ & & $29.94 \%$ & \\
\hline
\end{tabular}


The pandemic has caused many investors to view companies in a panic state, rendering them unconfident that larger companies will secure their investment. The global economy's downturn has signaled the investors that they need to diversify their portfolios into different assets, such as gold or other lower risk instruments. This condition is related to the signaling theory, in which investors receive signals from the companies and directly from external parties, namely the condition of stock exchanges in various countries that have been adversely affected by the COVID-19 pandemic globally. Therefore, whether the industrial sector is affected or not, the company's size does not guarantee that investors will believe its value will go up. Instead, they can assume that the value of a large company can go in the opposite direction. Investors' fear can be reflected in this result, and it can be seen from their disbelief that large companies are not necessarily stable and able to survive the shock of this pandemic. Thus, hypotheses $1 \mathrm{a}$ and $1 \mathrm{~b}$ are statistically not supported because the direction of the coefficient is not as predicted, even though it shows substantial results.

The leverage ratios in those two sectors are both positive and influential in determining firm value. Slightly deviating from what was predicted for the COVID-19 affected sector, leverage turned negative. However, results showed otherwise. This indicates that, for both the industrial sector affected by COVID-19 and not, the higher the company's leverage, the more the company value will increase. Similarly, Aggarwal \& Padhan (2017) found that leverage has a positive effect on firm value. This indicates that the company is optimizing more of its external funding. Surprisingly, companies in the industrial sector affected by COVID-19 also have a similar view, that is to maximize external funding in carrying out their operations even though the economic situation is uncertain and can threaten the possibility of default.

In this situation, it seems that the affected and unaffected industrial sectors respond to the current economic condition in a similar way, which is by trying to increase leverage with the objective of increasing firm value. In this case, investors tend to appreciate the signals given by the company. In the industrial sectors, affected or not affected, when the leverage ratio increases, their firm value also increases. Investors often use this to signal that the company still can pay its obligations even by raising the leverage ratio. Hence, it can increase the company's value albeit the risk of default because it is still in an uncertain condition. Investors are not worried about the risk of the company's increased capital from outside and the possibility of default. This is a sensitive matter for stakeholders. This reason is consistent with the first hypothesis, that investors may not interpret financial statements as well as the company's courage to increase firm value by increasing the leverage ratio. Therefore, hypothesis $2 a$ is rejected, but hypothesis $2 b$ is supported.

Table 5. shows that cash and profitability do not influence firm value for both companies in the industrial sector affected and unaffected by COVID-19, even though the expected coefficient directions are all in accordance with the predictions. That is, if profitability increases, it does not affect firm value. This is because an increase in the company's profitability will increase the company's profit per share. Nevertheless, with an increase in profitability, it is not confident that its share price will increase. Thus, if 
the profit per share increases but the share price does not, this situation will decline its value.

Although its significance does not affect, the direction of the positive coefficients for both sectors is in line with the hypothesis, which is also consistent with the research of Endri \& Fathoni (2020); Benyamin \& Endri, (2019); and Sabrin et al. (2016). A company's overall ability to generate profits with their total number of assets available measured by ROA. So, it plays a crucial role in maintaining the sustainability of a company in the long run, because profitability indicates the prospects of a company. If the managers can manage the company well, the company's costs will be smaller, further resulting in greater profits. The direction of the profitability coefficient, which is the ROA in these two sectors projects, also shows that, regardless of whether or not the industries affected by COVID-19 are different, a company's profitability has no effect on firm value. Therefore, hypotheses $4 a$ and $4 b$ are statistically not supported.

According to the formulated hypothesis, there is a difference in the direction of the cash coefficient between the affected and unaffected sectors, although it is not significant. The negative direction in the affected sector is in accordance with Lins \& Kalcheva (2007) findings, who found that cash ownership negatively affects firm value. Harford (1999) argues that when firms have cash reserves, they tend to engage in valueadding activities. Quite in the same vein, Myers \& Rajan (1998) assert that, in some cases where liquid assets, such as cash, are accumulated, management can turn them into personal gain, which, in the final analysis, has a negative impact on firm value. Meanwhile, the direction of the cash coefficient in the sector has no positive impact. This finding is also not in accordance with the results and arguments by Suartawan \& Yasa (2016), which states that free cash flow reflects cash that is available and is not used to finance the company's operational activities. Asante-Darko et al. (2018) acknowledge that a positive relationship may occur between cash reserves and firm value, but this occurs when cash reserves depend on other parameters. When cash reserves interact with the financial structure, there is a positive effect on firm value.

Ergo, it can be concluded that, for the sectors affected by COVID-19, holding excess cash by the company reduces its value because managers may be involved in activities that do not add value due to the excessive cash reserves and do not increase the company's operational cash flow, which can be said to be disrupted by its turnover. In contrast, for industries in the unaffected sectors, the companies have a higher value when they hold accumulated cash. Therefore, hypotheses $3 a$ and $3 b$ are statistically not supported.

The findings in this study are supported by the signaling theory. Signaling underpricing theories state that the issuing firms' managers are assumed to understand more about their firms' quality than outside investors. Impaired information makes investors unable to differentiate between high-quality firms and low-quality firms (Papaioannou \& Karagozoglu, 2017). In times of a pandemic like this, which causes the company's activities to experience sudden changes, managers are more aware of their condition than investors. An efficient capital market is sensitive to various kinds of signals published to investors without insider's intervention. Investors respond to signals given by the global market so that essential financial information is not noticed by 
Nugroho

The Effect of Financial Condition on Firm Value: A Comparative Study

Table 6. Difference in Difference Test

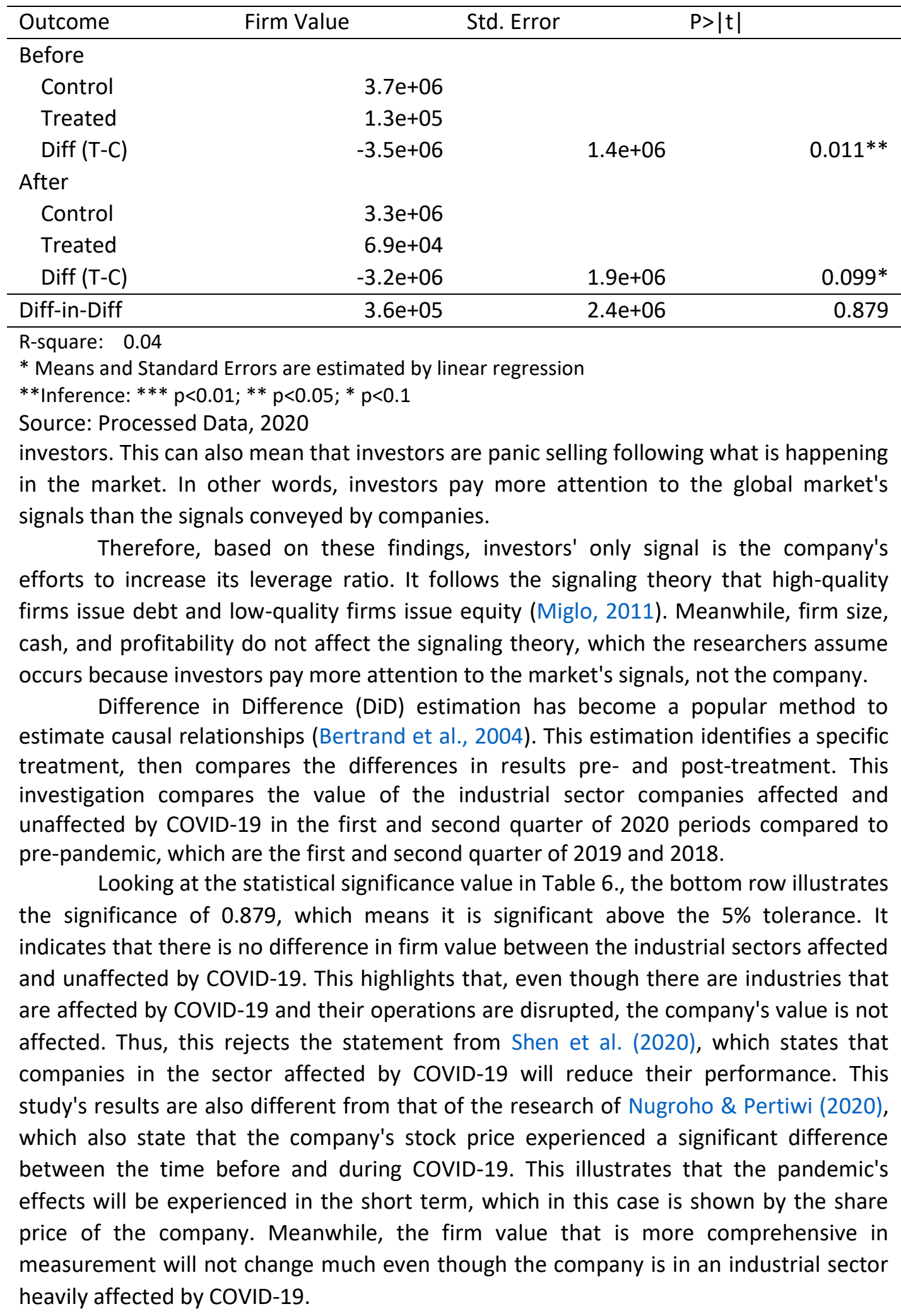




\author{
Nugroho \\ The Effect of Financial Condition on Firm Value: A Comparative Study
}

Ding et al. (2020) found that if investors' confidence in the disease outbreak mainly occurs domestically, then the diversification carried out by foreign investors affects increasing value. In other words, investors believe that this outbreak's impact will not last forever, and that it will improve over time so that it will insignificantly affect firm value. Hypothesis 5 in this study is thus rejected.

\title{
Conclusion
}

This study examines the relationship between the financial condition and firm value by comparing the sectors affected and unaffected by COVID-19. Additionally, we also conducted tests by looking at the influence of COVID-19 on company value before and when pandemics took place using the difference in difference (DiD) method. We predicted that all components of the company's financial condition would affect firm value. This research was carried out using data collected from the tourism, hotel, and restaurant sub-sector companies as the industrial sector affected by COVID-19, and the health, pharmaceutical, and telecommunications sub-sectors the as industrial sector unaffected by it, with the research period in the first quarter of 2018 until the second quarter of 2020.

We found that firm size and leverage impact the firm value in the affected and unaffected sectors. However, the appropriate direction of the coefficient is only leverage in the not-affected industrial sector. In addition, firm size has a negative direction coefficient. This means that the larger the company's size, the more the value of the company will decrease. This applies to both affected and unaffected sectors. These findings need to be explored deeper for further research. Also, we found no difference in company value between the industrial sectors that were affected and unaffected during the COVID-19 pandemic. This shows that the firm's value is more comprehensive so that it is less volatile than stock prices even though the global economy is experiencing a crisis.

This research is hoped to contribute towards both academics and practice. Academically, this study provides a fresh perspective in bridging literature related to economic responses during the crisis, fills the literature gap, and analyzes the impacts of the COVID-19 pandemic on the economy. Furthermore, this research also makes a significant contribution, primarily in assisting the government in issuing regulations to improve the competitiveness of the slumping economy and reflect as to how the protection of minority shareholders in the capital market is formed in Indonesia and the market's sensitivity. These findings can be a reference about the impacts of the pandemic on the capital market and how investors behave in responding to this phenomenon.

This study has limitations due to the scope of the study chosen that it cannot examine factors whose sources are not from financial reports. Given the research period chosen until the second quarter of 2020, we faced a difficulty in finding other factors whose sources cannot be obtained quickly and updated, such as financial reports. This study only compares several industrial sectors affected and unaffected due to the social restrictions and pandemic phenomenon. Therefore, it cannot be fully translatable into the general economic condition of Indonesia. 
There are still many opportunities to develop research related to the phenomenon of the impacts of COVID-19 on the economy experienced by companies operating in Indonesia. Over time, further research can also include the impacts of the announcement of a recession on stock movements if Indonesia's economic conditions exist under these conditions. Alternatively, if there is no recession, we can find out what causes the economy to grow then compare it to when the pandemic occurred. Subsequent research can also compare the impacts of COVID-19 across countries and consider the factor of foreign investors in seeing the capital market's reaction. Future studies can also link the effectiveness of companies during the pandemic.

\section{References}

Adams, R. B., \& Ferreira, D. (2009). Women in the boardroom and their impact on governance and performance. Journal of Financial Economics, 94(2). https://doi.org/10.1016/j.jfineco.2008.10.007

Adiputra, I. G., \& Hermawan, A. (2020). The effect of corporate social responsibility, firm size, dividend policy and liquidity on firm value: Evidence from manufacturing companies in Indonesia. International Journal of Innovation, Creativity and Change, 11(6), 325-338. https://www.ijicc.net/images/Vol11iss6/11629_Adiputra_2020_E1_R.pdf

Aggarwal, D., \& Padhan, P. C. (2017). Impact of Capital Structure on Firm Value: Evidence from Indian Hospitality Industry. Theoretical Economics Letters, 7(4), 982-1000. https://doi.org/10.4236/tel.2017.74067

Asante-Darko, D., Adu Bonsu, B., Famiyeh, S., Kwarteng, A., \& Goka, Y. (2018). Governance structures, cash holdings and firm value on the Ghana Stock Exchange. Corporate Governance (Bingley), 18(4), 671-685. https://doi.org/10.1108/CG-07-2017-0148

Batten, J., \& Vo, X. V. (2019). Liquidity and Firm Value in An Emerging Market. Singapore Economic Review, 64(2), 365-376. https://doi.org/10.1142/S0217590817470063

Benyamin, I. A., \& Endri, E. (2019). Determinants of Stock Returns of Building Construction Companies Listed on The Indonesia Stock Exchange Period 20122016. Scholars Journal of Economics, Business and Management, 6(1), 39-47.

Bertrand, M., Duflo, E., \& Mullainathan, S. (2004). How much should we trust differences-in-differences estimates? Quarterly Journal of Economics, 119(1), 249-275. https://doi.org/10.1162/003355304772839588

Brigham, E. F., \& Houston, J. F. (2014). Dasar-Dasar Manajemen Keuangan Edisi 11 Buku 1. In Salemba Empat Jakarta.

Connelly, B. L., Certo, S. T., Ireland, R. D., \& Reutzel, C. R. (2011). Signaling theory: A review and assessment. Journal of management, 37(1), 39-67. https://doi.org/10.1177/0149206310388419

De Vito, A., \& Gómez, J. P. (2020). Estimating the COVID-19 cash crunch: Global evidence and policy. Journal of Accounting and Public Policy, 39(2), 1-14. https://doi.org/10.1016/j.jaccpubpol.2020.106741

Ding, H., Fan, H., \& Lin, S. (2020). COVID-19, Firm Exposure, and Firm Value: A Tale of Two Lockdowns. SSRN Electronic Journal. https://doi.org/10.2139/ssrn.3574401

Ding, W., Levine, R., Lin, C., \& Xie, W. (2021). Corporate immunity to the COVID-19 pandemic. Journal of Financial Economics, 141(2), 802-830.

https://doi.org/10.3386/w27055 


\section{Nugroho}

The Effect of Financial Condition on Firm Value: A Comparative Study

Endri, E., \& Fathony, M. (2020). Determinants of firm's value: Evidence from financial industry. Management Science Letters, 10(1), 111-120.

https://doi.org/10.5267/j.msl.2019.8.011

FEB-UI, LPEM. (2020). Sustainable Economic Recovery from Covid-19: An Agenda for Indonesia. Working Paper.

Foster, A. D. (1995). Nutrition and health investment. American Economic Review, 85(2), 148-152. https://doi.org/10.2307/2117909

Gharaibeh, A. M. O., \& Qader, A. A. A. A. (2017). Factors influencing firm value as measured by the Tobin's Q: Empirical evidence from the Saudi Stock Exchange (TADAWUL). International Journal of Applied Business and Economic Research, 15(6), 333-358.

Gill, A., \& Obradovich, J. (2012). The impact of corporate governance and financial leverage on the value of American firms. International Research Journal of Finance and Economics, 91, 1-14.

Ginglinger, E., \& Saddour, K. (2012). Cash Holdings, Corporate Governance and Financial Constraints. SSRN Electronic Journal. https://doi.org/10.2139/ssrn.2154575

Hadiwardoyo, W. (2020). Kerugian ekonomi nasional akibat pandemi Covid-19. Baskara: Journal of Business and Entrepreneurship, 2(2), 83-92. https://doi.org/10.24853/baskara.2.2.83-92

Halimatussadiah, A., Cesarina, A., Siregar, A. A., Hanum, C., Wisana, D., Rahardi, F., ... \& Sofiyandi, Y. (2020). Thinking Ahead: Indonesia's Agenda on Sustainable Recovery from COVID-19 Pandemic.

Harford, J. (1999). Corporate cash reserves and acquisitions. Journal of Finance, 54(6), 1969-1997. https://doi.org/10.1111/0022-1082.00179

Indrawati, S. M., Diop, N., Ikhsan, M., \& Kacaribu, F. (2020). Enhancing Resilience to Turbulent Global Financial Markets: An Indonesian Experience. Economics and Finance in Indonesia, 66(1), 47-63. https://doi.org/10.47291/efi.v66i1.683

Jensen, M. C. (1986). Agency costs of free cash flow, corporate finance, and takeovers. The American economic review, 76(2), 323-329. https://doi.org/10.2139/ssrn.99580

Kalcheva, I., \& Lins, K. V. (2007). International evidence on cash holdings and expected managerial agency problems. The review of financial studies, 20(4), 1087-1112. https://doi.org/10.1093/rfs/hhm023

Maksum, N. A., \& Sirojuzilam, E. (2018). Value of The Firm In Capital Structure Perspective (Case study of Tourism Companies in Indonesia Stock Exchange). Economics, 6(1), 91-102.

Martínez-Sola, C., García-Teruel, P. J., \& Martínez-Solano, P. (2013). Corporate cash holding and firm value. Applied Economics, 45(2), 161-170. https://doi.org/10.1080/00036846.2011.595696

Miglo, A. (2011). Trade-off, pecking order, signaling, and market timing models. Capital structure and corporate financing decisions: Theory, evidence, and practice, 171-191. https://doi.org/10.1002/9781118266250.ch10

Myers, S. C., \& Rajan, R. G. (1998). The paradox of liquidity. Quarterly Journal of Economics, 113(3), 733-771. https://doi.org/10.1162/003355398555739

Njindan lyke, B. (2020). The disease outbreak channel of exchange rate return predictability: Evidence from COVID-19. Emerging Markets Finance and Trade, 56(10), 2277-2297. https://doi.org/10.1080/1540496X.2020.1784718 


\section{Nugroho}

The Effect of Financial Condition on Firm Value: A Comparative Study

Nugroho, D. S., \& Pertiwi, M. I. (2021). Stock Price Reaction when Covid-19 Exist: Moderating by Firm's Operating Cash Flow. Jurnal Ekonomi Malaysia, 55, 1.

Nunn, N., \& Qian, N. (2010). The Columbian exchange: A history of disease, food, and ideas. Journal of Economic Perspectives, 24(2), 163-88. https://doi.org/10.1257/jep.24.2.163

Papaioannou, G. J., \& Karagozoglu, A. K. (2017). Underwriting services and the new issues market. Academic Press.

Phan, D. H. B., \& Narayan, P. K. (2020). Country responses and the reaction of the stock market to COVID-19-A preliminary exposition. Emerging Markets Finance and Trade, 56(10), 2138-2150. https://doi.org/10.1080/1540496X.2020.1784719

Tulcanaza Prieto, A. B., \& Lee, Y. H. (2019). Internal and external determinants of capital structure in large Korean firms. Global Business \& Finance Review (GBFR), 24(3), 79-96. https://doi.org/10.17549/gbfr.2019.24.3.79

Wibowo, A. I. L., Putra, A. D., Dewi, M. S., \& Radianto, D. O. (2019). Differences In Intrinsic Value With Stock Market Prices Using The Price Earning Ratio (Per) Approach As An Investment Decision Making Indicator (Case Study Of Manufacturing Companies In Indonesia Period 2016-2017). Aptisi Transactions On Technopreneurship (ATT), 1(1), 82-92. https://doi.org/10.34306/att.v1i1.61

Ramelli, S., \& Wagner, A. F. (2020). Feverish stock price reactions to COVID-19. The Review of Corporate Finance Studies, 9(3), 622-655. https://doi.org/10.1093/rcfs/cfaa012

Revindo, M. D., \& Alta, A. (2020). Trade and Industry Brief. Seri Analisis Ekonomi.

Rjiba, H., Jahmane, A., \& Abid, I. (2020). Corporate social responsibility and firm value: Guiding through economic policy uncertainty. Finance Research Letters, 35. https://doi.org/10.1016/j.frl.2020.101553

Setiadharma, S., \& Machali, M. (2017). The effect of asset structure and firm size on firm value with capital structure as intervening variable. Journal of Business \& Financial Affairs, 6(4), 1-5. https://doi.org/10.4172/2167-0234.1000298

Sabrin, A., Sarita, B., Takdir, D., \& Sujono, C. (2016). The effect of profitability on firm value in manufacturing company at Indonesia Stock Exchange. The International Journal of Engineering and Science, 5(10), 81-89.

Shah, S. Z. A., \& Jam-e-Kausar. (2012). Determinants of capital structure of leasing companies in Pakistan. Applied Financial Economics, 22(22), 1841-1853. https://doi.org/10.1080/09603107.2012.678978

Shen, H., Fu, M., Pan, H., Yu, Z., \& Chen, Y. (2020). The impact of the COVID-19 pandemic on firm performance. Emerging Markets Finance and Trade, 56(10), 2213-2230. https://doi.org/10.1080/1540496X.2020.1785863

Spence, M. (2002). Signaling in retrospect and the informational structure of markets. American Economic Review, 92(3), 434-459. https://doi.org/10.1257/00028280260136200

Suartawan, P. A., \& Gerianta, Y. (2016). Pengaruh Investment Opportunity Set dan Free Cash Flow pada Kebijakan Dividen dan Nilai Perushaan pada Perusahaan Manufaktur Tahun 2011-2013. Jurnal Ilmiah Akuntansi dan Bisnis Universitas Udayana, 11(2), 63-74. https://doi.org/10.24843/jiab.2016.v11.i02.p01

Sujoko, \& Ugy, S. (2009). Pengaruh struktur kepemilikan saham, struktur modal, faktor intern dan faktor ekstern terhadap nilai perusahaan. Manajemen Dan Kewirausahaan, 9(1). https://doi.org/ 10.24034/j25485024.y2007.v11.i2.2236 
Wahyuni, F. (2018). Nilai Perusahaan, Indeks Tata Kelola Perusahaan dan Struktur Modal. Jurnal Ilmiah Akuntansi Dan Bisnis, 13(2), 151-160.

https://doi.org/10.24843/JIAB.2018.v13.i02.p08

Well, D. N. (2007). Accounting for the effect of health on economic growth. The quarterly journal of economics, 122(3), 1265-1306.

https://doi.org/10.1162/qjec.122.3.1265

Widarjono, A. (2018). Ekonometrika : Pengantar dan Aplikasinya. Jakarta: Ekonosia.

Zhang, J., Zhang, J., \& Lee, R. (2003). Rising longevity, education, savings, and growth. Journal of Development Economics, 70(1), 83-101.

https://doi.org/10.1016/S0304-3878(02)00088-3 